\title{
MANOEL GONÇALVES FERREIRA FILHO' - A DEMOCRACIA NO LIMIAR DO SÉCULO XXI
}

\author{
Fernando Aurelio Zilveti ${ }^{2}$ \\ Mestrando em Direito do Estado pela Faculdade de Direito da \\ Universidade de São Paulo.
}

O livro que a Editora Saraiva pôs no mercado, no primeiro semestre de 2001, vem confirmar a posição de Manoel Gonçalves Ferreira Filho como um grande constitucionalista brasileiro, engajado na discussão de.um tema clássico no estudo da ciência política, a democracia. A nova obra do professor titular da Faculdade de Direito da Universidade de São Paulo, composta de um volume, com 223 páginas, constitui uma confirmação de sua coerência científica e firmeza doutrinária que marcaram seus trinta de cátedra, quase vinte livros publicados e inúmeros artigos em revistas jurídicas, jornais e publicações científicas.

Manoel Gonçalves Ferreira Filho, acostumado a vencer desafios desde os tempos de aluno primário do Colégio São Luis, escrevera antes dessa obra sobre democracia, A Democracia Possivel, Editora Saraiva, 1972. Voltou ao tema em 1977. com o livro Sete Vezes Democracia, Editora Convivio, e em 1979, com o livro A reconstrução da Democracia, Editora Saraiva, sem contar que jamais se furtou a tratar do tema nas demais obras que publicou. Dissemos desafios, pois escrever sobre democracia em tempos de regime militar não foi tarefa fácil, ou lhe valeu a atenção de censores do Governo, por um lado, e a perseguição de quem ele mesmo chama em seu livro de intelligentsia brasileira. ${ }^{3}$ Essas obras sobre democracia, esgotadas em todas

1. O autor ć professor titular de Dircito Constitucional da Faculdade de Direito da USP. Doutor honoris causa da Universidade de Lisboa. Doutor pela Universidade de Paris. Ex-professor visitante da Faculdade de Dircito de Aix-cm-Provence (França). Membro da Comissão Exccutiva da Association Internationale de Droit Consitutioncl - AIDC. Presidente do Instituto "Pimenta Bucno" - Associação Brasilcira dos Constitucionalistas.

2. Advogado cm Sào Paulo, Professor de Dircito Constitucional.

3. Designação utilizada pclo autor, no prefácio de scu livro, para detcrminados grupos acadêmicos brasilciros que sc julgam democráticos, porćm defendem idcologias marxistas antilibcrais $\mathrm{c}$ rcacionárias. 
suas edições, foram de certa forma postas numa espécie de "index librorum prohibitorum" ", pela mesma intelligentsia brasileira.

Permanecendo firme na defesa do pensamento liberal, Manoel Gonçalves Ferreira Filho triunfou, sem precisar reformular suas idéias de democracia no curso histórico de trinta anos de grandes transformações, como o fracasso do comunismo e a derrocada do leste europeu. Ao contrário dele, outros pensadores festejados se viram obrigados a reconhecer haver abraçado causas infrutíferas, errando na crença obstinada da utopia de um mundo perfeito, uma "grande" causa que o indivíduo impõe não-só para si, mas também por imposição aos outros ${ }^{5}$ Como sentenciou Bobbio em entrevista recente: "no projeto utópico de transformação radical da sociedade está implícita uma idéia antiliberal, pois o liberalismo acredita que a história da liberdade é uma história de constantes passagens do bem para o mal, de tentativas fracassadas e falidas" Acrescenta, ainda o filósofo italiano: "Liberalismo é igual a antiperfeccionismo, ao passo que marxismo e nazismo foram utopias perfeccionistas ${ }^{6}$ "

Ferreira Filho expõe, num estilo sempre brilhante, toda a problemática da democracia, discute os seus aspectos com rigor científico, analisa minuciosamente diversos argumentos levantados a favor e contra as suas teses. Inicia o seu livro fazendo seis observações preliminares a respeito do regime de governo, forma de governo e sistema de governo. Para o autor, o regime fica no plano do ser, espelha uma realidade ou, quando o estudo é comparativo, um padrão de realidade; o sistema se situa no campo do dever-ser, um modelo normativo; e a forma de governo está no nível da essência (p. XIV).

Expõe a seguir o que chama de três visões de democracia, a dos antigos, a dos modernos e a contemporânea. Na descrição da democracia dos antigos, o autor afirma que Atenas foi uma democracia, pois nela, durante um periodo, o povo se governou diretamente. Ressalva, porém, com a pergunta: quem era o cidadão ateniense? De fato, cidadão ateniense era o homem nascido em Atenas, seu fillho homem, desde que filho de pai e mãe atenienses. Assim, numa população de 400 mil pessoas, apenas

4. O papa Urbano VIII, durante a Inquisição, detcrminava quc obras científicas, como o Diálogo, dc Galilcu Galilci, fosscm acrescentadas ao Index librorum prohibitorum $\mathrm{c}, \mathrm{cm}$ scguida, confiscados cxemplares para a bibliotcca do Vaticano c queimado o restante, por confrontar as idćias da Igrcja Católica.

5. Hobsbawm, Eric, Entrcvista a Antonio Polito, convertida no livro O Novo Século, São Paulo, 2000 , p. $191 / 192$.

6. Entrcvista concedida ao jornalista Gian Carlo Bossctti, ao jornal La Reppublica, traduzido c publicado no Brasil pclo jornal O Estado de São Paulo, cm 4 de fevcrciro de 2001, p. A19. 
$13 \%$ eram considerados cidadãos, o que justificava de certa forma o conceito de governo do povo pelo povo, na medida em que limitava o conceito de povo cidadão ateniense. Salienta, mais adiante, que o poder normativo ateniense deveria ser compatível com a razão, fonte do Direito, sob pena de nulidade, o que pode ser considerado o que chamamos hoje de controle de constitucionalidade, podendo ser o proponente e o responsável pela norma inválida sujeitos a penalidades (p. 5).

Após historiar brevemente o Estado ateniense e a crítica que os pensadores helênicos fizeram à democracia, às vezes sarcástica e às vezes elogiosa, finaliza o capítulo da Democracia Antiga, com menção à sistematização que Aristóteles fez das formas de governo, do poder legítimo, com um temor sempre atual, o de que a demagogia arruíne Atenas (p. 8). Ao dar seqüência às três visões de democracia, Ferreira Filho passa a discorrer sobre a democracia "moderna" esquecida desde Atenas até o século XVIII, exceção feita às Landesgemeinde ${ }^{7}$ dos cantões suíços. Para o autor, que denomina de "filosofia das luzes" esse período histórico, trouxe a democracia de volta aos debates das ciências sociais, tendo o cidadão genebrino Jean-Jacques Rousseau, como o responsável por sua sistematização rigorosa, para quem a vida em sociedade representa uma perda efetiva da liberdade individual, em troca da proteção do Estado que lhe garante a liberdade política, ao que Kelsen chamou de metamorfose da idéia de liberdade. ${ }^{8}$

Diferentemente do que há trinta anos, Ferreira Filho poupa a sistematização de Rousseau, segundo a qual cada um não deixaria, associado, de estar sujeito a si mesmo, continuando livre embora governado pela vontade geral.." O cerne da democracia "moderna" não estaria no "Contrato social", de Rousseau, que convencia seus leitores da inexequibilidade da democracia, mas sim no "O Espirito das Leis" de Montesquieu, que projetou uma forma de governo do povo pelo povo representado,

7. Mesmo no modelo considerado como descnvolvido de democracia dircta, como o suíço, as "Landgemeinde" ainda cxclucm do processo de criação da norma geral, os cstrangciros residentes $\mathrm{cm}$ scus cantõcs. Estes cstrangciros têm a permissão de lá viverem, porćm não podem cxercer o dircito que ć a mais pura cxpressão da liberdade individual na formaçāo da vontade geral. Não podem cles votar $\mathrm{ncm}$ ser votados - Bundesverfassung der Shweizerischen Eidgenossenschafi (Constituição da Confederação Suíça),abril de 1999, art. 37, "A cidadã ou o cidadão suíço são os titulares das leis da comunidade c dos cantõcs."...; também no art. 136, o dircito a voto ć restrito aos cidadãos suíços maiores de 18 anos (traduçào livre do autor).

8. Kclsen, Hans, General Theory of Law and State, Nova Jersci, 1999, p. 284.

9. Na A Democracia Possivel, São Paulo, 1972, p. I0, Ferreira Filho considerou o csquema de Rousscau totalmentc incompativel com a realidadc. 
indicado para grandes Estados, com representantes mais capazes de governar, segundo sua própria razão, transparecendo aí um elemento aristocrático (p. 13). A democracia "moderna" é caracterizada pela representatividade, que deve garantir ao povo uma participação relativa na obtenção da vontade geral e na contenção do poder. $\mathrm{Na}$ democracia dos partidos, estes seriam agentes constitucionais de formação da vontade do Estado, como explica Kelsen, possível sempre que os partidos tivessem um programa de governo rígido, aprovado pelo povo e, depois de eleitos os representantes, estes executassem esse programa.

Como descreve Ferreira Filho mais adiante, a democracia representativa, para vingar, pressupõe um bipartidarismo que raramente se instaura (p. 22). E mais, não prescinde a mesma democracia da fidelidade partidária, de uma garantia que o poder conferido ao representante possa ser aferido e, no caso de quebra de legitimidade, possa se dar a perda do mandato, o que se traduz no mandato imperativo. ${ }^{10}$ Para aprimorar a democracia moderna, foi introdụzida a idéia de maior participação do povo na obtenção da vontade geral, por meio do referendo, a iniciativa popular, o plebiscito, o veto popular, e outros. Bem adverte Ferreira Filho, para o risco dessa maior participação servir a interesses pouco democráticos (p. 23), o que nos leva a crer na necessidade de um aprimoramento das formas do exercício da vontade do povo na obtenção da vontade geral.

Na seqüência de sua descrição sobre as três democracias, o professor catedrático da Faculdade de Direito da USP lança algumas constatações, idéias-força, defendidas por diversos juristas e por ele próprio, como a de que o povo não se governa; " que na sociedade moderna, pela complexidade das relações, é inviável que todos, ou a maioria, desempenhem a tarefa de governar; ou a de quem governa é sempre uma minoria (p. 31).

Empiricamente vista, segue Ferreira Filho, a democracia contemporânea seria uma forma de governo em que o povo participa decisivamente da escolha dos seus governantes, devendo ser chamado para decidir, também, diretamente, questões de grande relevância. Isso sem contar com a possibilidade de destituir quem se afaste da legitimidade que o mandato pressupõe (p. 32). A preocupação da doutrina contemporânea é com a chamada democracia participativa, aquela que vai além da iniciativa popular, do referendo e do plebiscito. Algumas sistematizações dessa

10. Kclsen, Hans, General ..., op. cit., p. 290.

11. Ferreira Filho, Manocl Gonçalves, A Democracia Possivel, op. cit. p. 21 
democracia participativa são feitas pelos estudiosos da ciência política, prevendo-se uma participação mais direta na base e por delegação em cada nível acima da base, um sistema piramidal, segundo V.C.B. Macpherson. ${ }^{12}$

Lançando, ainda que timidamente, um tema novo no debate da democracia participativa, Ferreira Filho trata da democracia direta eletrônica. De fato, o que pareceria uma ficção científica há alguns anos, hoje é considerada uma revolução no conceito da participação popular na obtenção da vontade geral (p. 35). Pela televisão, telefone e mais recentemente, pela Internet, é possível a participação do cidadão no governo de forma direta, e no sufrágio universal, de forma indireta, elegendo seus representantes. Recebida com ceticismo por alguns e celebrada por outros, a verdade é que ainda não se viveu muita experiência neste campo, nas diversas democracias ocidentais. Nos EUA, por exemplo, onde a Internet é uma realidade há muitos anos, o seu uso para o sufrágio é bastante tímido, devido ao atraso dessa nação nesse setor, como demonstraram ao mundo nas últimas eleições para a Presidência. Saliente-se, por oportuno, que no último pleito para presidente dos EUA, houve o uso da internet, em caráter experimental, em algumas cidades da Califórnia, facultando ao cidadão, com o auxílio de uma senha, votar de sua casa, pela Rede Internet, ${ }^{13}$ imprimindo, ao final, um comprovante de "comparecimento", semelhante ao que, no Brasil, é utilizado para os contribuintes do Imposto de Renda.

Sempre interessado no tema da democracia, Ferreira Filho conclui o capítulo sobre a democracia contemporânea, fazendo uma crítica sobre a presença nesse modelo, do elemento da representação, que somente pode ser eliminado pela democracia eletrônica, embora ninguém até hoje aposte suas fichas nessa hipótese (p. 36).

Depois de analisar as três visões de democracia, Ferreira Filho passa a examinar aquilo que afeta, negativa e positivamente, a democracia. É preciso que cada fator seja compreendido isoladamente, facultando ao exercício liberal da busca da utopia democrática desenvolver meios de aperfeiçoar o conceito de governo do povo pelo povo. Existem, segundo o autor, presidente-fundador da Associação Brasileira dos Constitucionalistas - Instituto Pimenta Bueno, condições institucionais e instrumentais

12. Macpherson, V.C.B., A democracia liberal, Rio de Janciro, 1978, p. 103 c ss;

13. Cf., artigo publicado na Internet, www.votc.org. No mesmo "site" ć possível encontrar diversos artigos c "links" para outros "sites", demonstrando a tendência do uso da internet, não só como instrumento de voto para cleição de representantcs, mas também para as iniciativas popularcs Icgislativas, o que demonstra uma grande ćvolução no conccito de sufrágio. Vide, também o "site" www.brunozo.cng.br/ voto-c/textos. 
do regime democrático, pois este é afetado por fatores sociais e econômicos (p. 37). Dentre os fatores sociais, o psicossocial é considerado por Ferreira Filho como subjacente a todos os outros aspectos, porém, que não pode ser deixado de lado. $\mathrm{O}$ estudo do homem e de sua natureza, que rendeu muitas reflexões dos pensadores é, sem dúvida, um fator de grande importância na compreensão da democracia. Pode o homem ser naturalmente ruim, na visão de Hobbes e, se não houver um poder ereto, como defesa pode o homem se valer de sua própria força contra todos os demais: $;^{14}$ pode, por outro lado, ser naturalmente bom, sendo corrompido pelo meio social, como entende Locke; ${ }^{15}$ ou ainda, na visão de Rousseau, nem bons nem maus, sem vícios ou virtudes, no estado da natureza. ${ }^{16}$ Mais adiante, Ferreira Filho reconhece que a maioria acredita na bondade natural do homem, porém reconhece em si e nos demais um potencial de maldade que, por precaução, deve ser contido pelo Estado (p. 45).

Uma importante abordagem feita pelo autor, ainda sobre a questão psicossocial, trata do processo de socialização pela qual passa o homem desde sua infầncia. Ferreira Filho cita o exemplo do cidadão americano, que adquire uma preferência partidária desde a adolescência. Com razão, o autor empresta idéias de Montesquieu para afirmar que um governo democrático deve educar seu povo na virtude, incutindolhe princípios como o de colocar o interesse geral acima do interesse pessoal ${ }^{17}$ Os princípios de um povo constituem, assim, a essência de cada forma de governo (p. 47).

Alem da questão do princípio democrático, Ferreira Filho examina o caráter de uma sociedade, tomando por base um estudo de David Riesman sobre o tema. De acordo com Riesman, existiriam três tipos de indivíduos: o "traditiondirected", o "inner-directed" e o "other directed". O primeiro está ligado às tradições, à idéia do "porque sempre foi assim" O segundo está ligado aos princípios que norteiam sua conduta, de inspiração iluminista. $O$ terceiro é o dirigido pelos outros, pouco crítico a ponto de se ajustar facilmente ao que os outros dizem. Segundo sintetizou Ferreira Filho, cada um desses tipos reage de forma diversa em face da democracia, o primeiro se sente desconfortável, pois prefere não ter que decidir, o que é próprio da democracia,

14. Hobbes, Thomas, Leviathan or the matter; forme and power of a commonuealth ecclexiastical and civil, Nova lorquc, 1997, p. 129.

15. Lockc, John, Two Treatises of Government, Londres, 2000, Capitulo II, n. 6.

16. Rousscau, Jcan-jacques, Disconus surl'origine et les fonde'ments de l'inégalité parmi les hommes, Paris, 1973, p. 57 c ss.

17. Montesquicu, Charles de Secondat, Barão de, De l'esprit des lois, Paris, 1995. Livro III, Capitulo III. 
preferindo que se proceda de acordo com as tradições; o segundo vive bem na democracia, como se ela fosse feita para ele; o terceiro é manipulado pela mídia, sendo suscetível a opiniões de outros, o que turva sua convicção (p. 51). Nos dias de hoje, observa Ferreira Filho, o terceiro tipo tende a crescer diante da expansão da globalização, que encanta a mídia, formando a opinião daqueles, como a intelligentsia, fracos em conteúdo crítico e intelectual.

Ainda no mesmo tema psicossocial, Ferreira Filho menciona seu próprio trabalho $A$ Reconstrução da Democracia ${ }^{18}$, para lembrar a elaboração feita sobre o caráter nacional, obra em que criticou o brasileiro, individualista, cordial e copista, pouco afeto à participação política. Aqui vemos que o caráter nacional, da mesma forma que o pessoal, sofre uma grande influência da formação de princípios sociais desde a mais tenra idade. Mais adiante ressalta o autor que o homem democrático se caracteriza pelo racionalismo, que pode convencer o individuo a ceder aos sentimentos coletivos para a obtenção da vontade geral; isso desde que delibere suficientemente informado e com os princípios liberais estudados acima (p. 53). Essa teoria racional de Rousseau, mencionada pelo autor, é utópica, pois o racionalismo não-reina soberano, mesmo no cidadão suficientemente informado, sendo sujeito a condutas não-lógicas, que ele tem dificuldade em aceitar e inventa. Como Ferreira Filho conclui, esse sujeito dá explicações racionais para seu ato ilógico. Aqui cabe a colaboração de Bobbio, para quem houve no curso da história do pensamento ocidental, quem defendesse a desigualdade e quem defendesse a igualdade entre os homens, ${ }^{19}$ cada qual vivendo realidades históricas distintas, que, ao nosso ver, alimentavam sua retórica para justificar determinados sistemas de dominação. O não-lógico, portanto, tem um peso significativo na atividade humana (p. 54).

Mais adiante, o autor cita um trabalho de Anthony Downs a respeito da teoria econômica da democracia, para ressaltar os nítidos limites da racionalidade nas decisões políticas dos homens, pautadas por interesses pessoais e circunstanciais. Num outro ensaio, Ferreira Filho utilizou uma pesquisa feita nos EUA, para afirmar que o eleitor vota, mais das vezes, desinformado, fato revelado em outras pesquisas feitas no Brasil e no Exterior. Esses dados, contudo, pouco contribuem para o debate sobre a democracia, senão apenas indicam uma apatia do cidadão moderno em relação ao poder governante, que justifica a abstinência eleitoral nos países onde o voto é facultativo, como a França, os EUA e a Suíça.

18. São Paulo, 1979, p. 61 c ss..

19. Bobbio, Norbcrto, As ideologias e o poder en crise, Brasilia, 1995, p. 39. 
Provocando o leitor, uma vez mais, a refletir sobre aspectos desconfortáveis da democracia, Ferreira Filho retoma o debate sobre a cultura política (p. 58). A cultura aqui descrita como pressuposto da democracia, não é apenas a proveniente da educação acadêmica, mas também e principalmente, dos valores morais e éticos, costumes quase naturais do homem, como a dignidade pessoal, o culto da família, amor à liberdade, à igualdade, Humanidade, respeito à lei, devotamento a causas públicas, individualismo, altivez, honra, independência, altruísmo, espíritọ de sacrifício; que podem todos ser resumidos em um único sentimento-conceito, qual seja, o de Justiça. É bem verdade que há diferentes experiências de cultura política de povo para povo, como salienta Ferreira Filho, variáveis da proporção direta da diversidade cultural de cada povo e da construção de seus valores ancestrais, o que definiu como a cosmovisão de cada povo. A cultura, como valor democrático, entendida por John Rawls como Law of Peoples, é o conteúdo da razão popular gerado pela família a partir de princípios liberais de Justiça. ${ }^{20}$ Esses princípios culturais devem ser profundamente estudados para que se entenda como aplicá-los nas relações políticas entre as pessoas. A cultura política, acima de tudo, tem uma grande importância na aferição da legitimidade do tipo de governo, a cosmovisão, isto é, a concepção da vida e do mundo, valores que o cidadão tem sobre o direito. ${ }^{21}$ Essa seria a capacidade política do povo que representa o poder constituinte. ${ }^{22}$

Quando Ferreira Filho analisa, então, as condições socioeconômicas e a democracia, algumas questões se impõem. O pressuposto econômico da igualdade é a Justiça social exercida pela melhor distribuição da renda, facultada pelo crescimento econômico do Estado, o que dá ao cidadão as condições básicas para a sua subsistência e, conseqüientemente, maior disponibilidade para dedicar-se ao exercício do poder. ${ }^{23}$

Assim, o pressuposto econômico não é material, como pode ser falsamente entendido, mas um objetivo de satisfação mínima das necessidades do povo.

20. Rawls, John, The Law of Peoples with The ldea of Public Reasons Revisited, Harvard University Press, Londres, 1999, p. 57.

21. Ferreira Filho, Manocl Gonçalves, O Poder Constituinte, São Paulo, 1985, p. 44.

22. Schmitt, Carl, Verfasstungslehre, Munique c Lipsia, 1928, p. 238 - "Jede Verfassung beruht nach demokratisclier Auffassung auch in ihrem rechtstaatlichen Bestandtcil auf der konkretcn politischen Entsclıcidung des poltisch handlungsfähtigen Volkes" - traduzindo: " Toda a Constituição, segundo a conccpção de democrática, bascia-sc, inclusive para scu clemento de Estado de Dircito, na decisão politica concreta do povo dotado de capacidade política.

23. Schumpeter, Joscph A., Teoria do Desenvolvimento Econômico, São Paulo, 1982, p. 12. 
A partir da satisfação do mínimo existencial, pode o povo destinar parte de suas atenções para a melhoria das relações sociais e, com isso, seja mais um na luta pela obtenção da vontade geral pela vontade da maioria. Aqui o autor faz menção à tese marxista sobre a condição socioeconômica do homem, em que a existência social determina a sua consciência, formada pelas relações materialistas que fazem a estrutura da sociedade, reconhecendo que o marxismo contribui para "a conscientização da importância dos aspectos econômicos na formação dos regimes de governo" (p. 69). O problema de grande parte da população mundial, principalmente após a queda do comunismo e o efeito da globalização, é a escassez de recursos. Para criar um substrato no qual a democracia possa se desenvolver é imperativo que se elimine a miséria, atenuando a pobreza, criando condições para que o povo possa se alimentar, vestir, morar, de modo que seus valores culturais democráticos, dentre eles principalmente a dignidade e a altivez, possam se sobressair, dando condições ao desenvolvimento do raciocínio coletivo. Como prova dessa afirmação, podemos citar o trabalho estatístico de Robert Dahl, que contabilizou a existência da democracia em todos os países desenvolvidos, enquanto apenas $13 \%$ (na época desse trabalho, ou seja, em 1971) dos países nãodesenvolvidos viviam na democracia. ${ }^{24}$ Finalizando o capítulo 6, Ferreira Filho cita seu livro A Democracia Possivel, ${ }^{25}$ em que desenvolveu esse tema socioeconômico, deixando claro que não há democracia sem que se resolva o problema da miséria. Em outras palavras, o mínimo existencial, considerado por alguns juristas como um direito fundamental ${ }^{26}$ é condição para a vida em sociedade, conseqüentemente, para a democracia.

Mais adiante na questão da democracia, Ferreira Filho desenvolve um interessante raciocínio sobre o que designou como "fatores sociais obstaculizantes" da democracia (p. 79). Dentre os problemas sociais, podemos ressaltar a questão das minorias que foram no passado generalizadas como apẹnas aquelas de natureza étnica. Hoje são tendenciosamente ampliadas para além desses limites. Existem, porém, outros problemas sociais de igual relevância, como o pretorianismo e a corrupção, típicos das democracias novas ou democracias de países com instituições fracas, como boa parte dos países da América do Sul. 1973.

24. Fcrrcira Filho, Manocl Gonçalvcs, p. 70. O autor cita Dahl cm scu livro Polyarchy, Nova Iorque,

25. Op. cit.. p. 33 c ss.

26. Torres, Ricardo Lobo, Curso de Direito Financeiro e Tributário, Rio de Janciro, I999, p.61. 
Vários grupos se autodenominam, atualmente, como minorias sexuais, religiosas, de costumes, de ideologia, etc.. Passoul-se a entender como minoria as diferenças pessoais, o que representa, ao nosso ver, um risco de sectarização antiigualitária que divide o povo na luta pela contenção do poder, sonho de qualquer democrata contemporâneo.

A movimentação das minorias tomou vulto com a causa negra, seguida da causa feminista, que lutaram e ainda lutam, para a melhoria das relações sociais, havendo conquistado inúmeros avanços igualitários no último século. Como toda a bandeira política revolucionária, a causa das minorias também trouxe mudanças que, no íntimo, podem resultar em desigualdades.

O exemplo atual desse perigoso desvio é o caso da reserva de cadeiras para o sexo feminino, no Parlamento francês. Pois bem, nas eleições municipais do ano 2001, na França, cumpriu-se a nova lei eleitoral, que garante às mulheres o direito de um mínimo de cadeiras no Parlamento, igual aos homens. Com essa modifícação, o Parlamento francês deverá ter a partir dessas eleições municipais, um numero igual de homens e mulheres ocupando as cadeiras do Parlamento. Essa discriminação positiva pode, numa primeira análise, representar um avanço nas relações políticas igualitárias. Na verdade, contudo, é terrivelmente discriminatória, pois em nome da causa feminista, essa falsa igualdade deixou de fora todas as demais "minorias" e, mesmo que no futuro essa tendência seja ampliada para "todas as minorias". o que se fará será multiplicar os sectos, dando vazão à criação de novas "minorias" num círculo vicioso que não mais terá fim. ${ }^{27}$

Outro problema para a democracia ou a retenção do poder, na visão mais contemporânea, é o pretorianismo. O pretorianismo, ou seja, a participação, de forma eventual ou perene, das forças armadas na administração de um Estado e na formação da vontade geral, é um fenômeno observado nas democracias instáveis de boa parte dos países pobres. O que na democracia ateniense era compreendido como uma condição de cidadania e, conseqüientemente, de direito à participação na obtenção da vontade geral, nos Estados mencionados, consiste simultaneamente, na garantia e na ameaça ao estado de direito, dependendo da forma e intensidade em que manifeste sua intervenção no poder (p. 90).

Ferreira Filho analisa a corrupção, para que não esqueçamos de um grave problema para as democracias do mundo atual. Associado com certo parti pris aos 
países pobres e de pouca tradição história democrática, ${ }^{28}$ o fenômeno da corrupção é analisado com certa assepsia, pois é um tema normalmente tratado como denúncia e não como fenômeno da personalidade humana. A corrupção nos vários níveis de governo ou de estado, por meio do oferecimento de vantagens em troca de favores políticos ou pecuniários tira a legitimidade do representante do povo, retirando-lhe um pressuposto essencial do mandato, qual seja, a fidelidade.

O combate ao fenômeno da corrupção pode ser feito de diversas maneiras, dentre elas, a elaboração de leis, o aumento do controle popular e o fortalecimento das instituições democráticas. Dessas três armas, apenas o controle popular tem obtido melhores resultados, quando não contaminado pela hipocrisia, ou quando não-se presta ao papel de inocente útil, iludido pela mídia ou por outras forças de formação da opinião pública. Com certa freqüência as leis e as instituições elevam o nível da corrupção, ao invés de detê-la, como demonstra a história recente da reunificação alemã e da Comunidade Econômica Européia.

A chamada patologia da democracia, analisada com propriedade por Ferreira Filho, tem como remédio mais eficaz, pela constatação da inexistência de cura definitiva até então, o fortalecimento institucional. Entendemos como instituições democráticas aquelas que contribuem para dar maior legitimidade na formação da vontade geral, como a existência do Estado de Direito, a limitação eficaz do poder constituído e a garantia ao respeito desse Estado, mormente realizada pelo Judiciário.

Partindo das bases psicossociais e econômicas, chega o professor do Largo de São Francisco à discussão sobre as condições institucionais que propiciam a democracia num Estado de Direito. Como Estado de Direito temos a lei fundamental, a norma geral e abstrata, capaz de consagrar os direitos do cidadão e sua vontade geral. O rule of law, como os ingleses elaboraram, a predominância da lei na determinação dos rumos do Estado, tem como características principais a validade e eficácia erga omnes e a sua consagração pela garantia judicial. Lembremos que a norma geral que

28. Nessa análisc, o autor, accrtadamentc, denuncia que o corruptor cstrangciro tem um papel detcrminante na corrupção dos paises pobres ou cm descnvolvimento, pois a corrupção que hesitaria cm fazcr cm seu país, faz na terra alhcia. Acrescentc-sc, por oportuno, que os cstrangciros cvitam a corrupção $\mathrm{cm}$ scu território por temor à sanção lcgal ou social, cnquanto permciam a corrupção alhures. Como cxcmplo da accrtada obscrvação do autor, podemos citar o trabalho scmi-cscravo na China, condenado pelos países ricos na Organização Mundial do Trabalho - OIT c na Organização Mundial do Comércio OMC, cnquanto, nessc mesmo pais, grandes cmpresas curopćias não sc incomodam cm manter os scus trabalhadores cm cárcere privado, sem dircitos sociais c com salários de US\$1,00 ao dia, protcgidos pela corrupta máquina administrativa chincsa, inundando o mercado mundial com produtos "made in china". 
assegura a unidade do todo é a lei, e quem tem o poder de fazer leis, de conceder normas de conduta, é o verdadeiro soberano. ${ }^{29}$

$\mathrm{O}$ rule of law, originariamente inglês, e como tal mais flexível se transformou na doutrina jurídica do Estado, no "continente europeu" em estado de Direito, porém com uma força mais opressora diante do positivismo romano-germânico. Subordina-se, assim, todo o poder ao direito, do nível mais baixo ao mais alto, por meio da legalização de qualquer ação do governo, o que pode ser resumido em constitucionalismo. ${ }^{30}$ Aqui notamos uma convergência dos pensamentos de Ferreira Filho e Bobbio (p. 97).

A legalidade e seu predomínio absoluto dá sentido à separação de poderes, desde que se entenda por lei a norma geral, não devendo esta ser confundida com a definição formal de lei, como tudo que se faça dentro do procedimento legislativo dos órgãos competentes para legislar. O império da lei, entretanto, não deve também ser confundido com o império do poder legislativo, como fazem alguns doutrinadores.

Como bem observa Carl Schmitt, dar ao legislador o poder absoluto apenas mudaria de mãos o absolutismo, outrora combatido para subtrair o poder absoluto do monarca, correndo o risco de criar o absolutismo das várias cabeças dos partidos políticos que em cada momento se encontrassem em maioria ${ }^{31}$. Como observa Ferreira Filho (p. 107), citando o mesmo Carl Schmitt, legalidade e igualdade estão indissoluvelmente ligadas ${ }^{32}$, não cabendo espaço para o absolutismo desse poder.

No capítulo 9, Ferreira Filho passa, então, a analisar como funcionam os princípios fundamentais que configuram a constituição, ao que Mainhofer chamou de democracia em liberdade: por um lado, os princípios de liberdade e igualdade e, por outro, os princípios de legitimidade e de separação de poderes, que se combinam de uma maneira que se construa a democracia participativa e constitucional, mas igualmente

29. Bobbio, Norbcrto, Il Futuro della Democrazia, 1984, Milão, p. 144.

30. Bobbio, Norberto, Il Futuro..., op. cit., p. 174. - Necessário csclarecer que os juristas não ingleses consideram a Inglaterra como uma ilha curopéia, de modo quc, quando fazem referencia ao "contincnte": querem excluir a Inglaterra do contexto.

31. Schmitt, Carl, Verfassungslehre, Munique c Lipsia, Duncklcr \& Humbolt, 1928, p. 152 tradução do texto original: "Wenn das heute geltendes Verfassungsrecht wärc, so hätte der ganzı recthstaatliche Kampf gegend den Absolutismus des Monarchen damit gecndet, das an dic Stclle de: monarchischen Absolutismus der vielköpfige Absolutismus der jeweiligen parteipolitischen Mehrhei getreten wärc."

32. Schmitt, Carl, Verfassungslehre, ... op. cit., p. 154. 
liberal e social. ${ }^{33}$ Neste estudo, o autor inicia seu raciocínio com os Direitos Humanos, vistos pelos helênicos como um direito superior, em virtude de sua própria existência, ao Direito Positivo. ${ }^{34}$ Vistos como naturais até o século XVIII, os direitos fundamentais não reclamavam contrapartida positiva do Estado, senão apenas sua atuação como garantia contra a subtração e o abuso. Com a inauguração do Estado social, este passou de garantidor a sujeito passivo do direito humano, isto é, aquele com a obrigação de prover o cidadão com determinado direito, com o trabalho, previsto na Constituição de Weimer, de 1919. Bem verdade que os direitos fundamentais, fracassada a idéia do Estado providência, mesmo que alargados em número, pressupõem uma limitação da ação estatal ao estabelecer os seus lindes e agir na medida exata da correção de desequilíbrios que possam pôr em risco os mesmos direitos, provendo somente os direitos econômicos e sociais (p. 118).

A teoria desenvolvida por Montesquieu propôs que "le pouvoir arrête lê pouvoir" ${ }^{35}$ ou seja, um Estado constituído organizacionalmente por três poderes distintos (Executivo, Legislativo e Judiciário), com autonomia própria e funções estabelecidas constitucionalmente, erigindo obstáculos para a tendência monopolizadora do poder, por meio do controle recíproco de cada instituição ${ }^{36}$ Como diz Ferreira Filho, essa teoria rejeita a concentração do poder numa só mão, num só órgão (p. 121). De fato, no Estado liberal é possível reconhecer, então, a presença de três poderes, sendo o Legislativo aquele soberano, resultado da vontade geral; o poder Executivo

33. Mainhofer, Werner, Introducción: Concepto y Objeto de la Democracia em la Ley Fundamental, in Manual de Derecho Constitucional, de Benda, Mainhofer, Vogel, Hesse c Hegel, traduzido por Antonio Lópcz Pina, Ed. Marcial Pons, Madrid, 1996, p.222.

34. Fcrreira Filho, Manocl Gonçalves, Direitos Humanos Fundamentais, São Paulo, 1988.

35. Alguns autorcs entendem que Montesquicu cquivocou-sc na interpretação do Estado inglês, sendo que outros entendem que cstc cquivoco foi proposital, a fim de forçar a validade das suas idéias sobre a neccssidade da separação radical dos poderes do Estado, substituindo a figura do monarca pela constituição cscrita. Vide Schmitt, Carl, Verfassungslehre, Bcrlim, 1928, p.203: "A doutrina do cquilibrio de poderes c a doutrina da forma mista de governo sc interpenetram aqui rcciprocamentc. Montesquieu accita $\mathrm{c}$ modifica a sua mancira discreta, cstas idćias $\mathrm{cm}$ uma doutrina da degeneração das formas de governo; cle acredita que o idcal consiste na mistura de aristocracia c monarquia, c um governo bem equilibrado", tradução do texto original alcmão $\mathrm{cm}$ que sc lê: "Montesquicu übernimmt und modifiziert in seiner klugen Wcisc diesc Gedankengängen in cincr Lehre von der Entartung der Staatsform; er hält cine Mischung von Aristokratic und Monarchic und einc gut temperierte Regierung für das Ideal.

36. Montcsquicu, Barão de, De L'Espirit des Lois; Paris, 1995, Livro Décimo Primeiro, Capitulo VI, "Quando, na mesma pessoa ou no mesmo corpo de magistratura, o poder legislativo cstá reunido ao poder cxecutivo, não existc liberdade; porque se pode temer que o mesmo monarca ou o mesmo senado cric leis tirânicas para executá-las tiranicamcnte" 
que age de acordo com a lei; e o Judiciário que reconhece, em cumprimento à lei, o que cabe a cada um. Este silogismo da ordem estatal, como quis Kant, caracterizava o legislativo como "irrepreensível”, o Executivo como "irresistível” e o Judiciário como "inapelável" 37 Esses poderes, chamados por Kant de "dignidades" devem viver em harmonia, vedada a usurpação de funções entre eles.

A regra de distribuição de competências orgânicas, ${ }^{38}$ além de visar o controle do poder do Estado, tem também uma fundamentação prática de especialização das instituições integrantes da organização estatal. A ordem política do Estado deve ser de tal forma harmoniosa, de modo a deixar o cidadão com a nítida impressão de uma unidade do Estado, ciente, entretanto, da autonomia e independência dos poderes garantes da sua liberdade individual. A distribuição orgânica traduz uma separação subjetiva, em que os agentes Executivo, Legislativo e judiciário, têm funções definidas, porém podem uns e outros, agirem, respeitados alguns limites, com funções dos outros.

Mais adiante, aborda Ferreira Filho a questão da descentralização do poder central, que serve bem à democracia, pois impede o abuso na medida em que distribui os agentes do poder e estabelece métodos de controle mútuo. Dentre as técnicas de divisão de poderes, o autor menciona o federalismo e os poderes locais. Relatando a história dos poderes locais, desenvolvidos em Estados como Portugal, nos quais o poder se iniciava de forma periférica, mais efetiva diante das dificuldades tecnológicas, como a comunicação e o transporte. Em seguida, o autor cita os exemplos da Espanha e Itália, onde os poderes locais têm uma autonomia regional, figurando como um contrapeso ao Poder Central (p. 124).

Ao tratar do Federalismo, Ferreira Filho faz uma pausa para explicar a origem etimológica da palavra, que vem do latim foedus, significado de aliança. Com efeito, a aliança levada a cabo nos primeiros Estados federais como a Suíça e os EUA, não veio de uma descentralização, mas sim de uma concentração estratégica de Poder, em que a federação foi sistematizada para garantir autonomia relativa aos Estados aliados, na contrapartida da cessão de poderes de representação externa e de coordenação interna à União. A exceção histórica do Federalismo brasileiro serve para explicar melhor a técnica de descentralização, em que se admite uma pluralidade de poderes, com relativa autonomia e capacidade de contrapor ao Poder Central (p. 127).

37. Kant, Immanucl, Metaphysik der Sitten, Francofortc no Mcno, 2000, p.139. 190.

38. Miranda, Pontes de, Comentários à Constituição Brasileira de 1946, Sào Paulo, 1953, vol. I, p. 
Concluindo o item ' $\mathrm{B}$ ' sobre as condições institucionais da democracia, o professor titular de Direito Constitucional da USP discorre sobre a garantia judicial.

Ao iniciar sua exposição sobre a Garantia Judicial, o professor Ferreira Filho faz um jogo de frases que, numa primeira vista poderia parecer acaciano, porém, em sistemas democráticos frágeis como o Pátrio, seu significado precisa ser constantemente relembrado. Diz Ferreira Filho que se é verdade que quem tem o poder tende a dele abusar, é imprescindível um meio eficaz de repressão do abuso, sob pena desse poder ficar ilimitado (p. 128).

Para a limitação do poder ainda não se viu forma melhor, como sentencia Ferreira Filho, do que a existência de juízes independentes e imparciais, cujas decisões sejam aplicadas de modo imperativo. Para tanto é preciso a especialização e a elevação do juiz ao grau de poder, o Poder Judiciário, equiparando-o aos poderes tradicionais, justamente para poder "empecher" aquele que abusa do direito. De fato, ao contrário das democracias desenvolvidas, onde se vê o Poder Judiciário como bastião da Justiça, as frágeis e instáveis democracias tendem a buscar diversas formas de limitar o poder, de acordo com suas próprias convicções culturais e políticas, criando outras formas de controle informal jurisdicional, com forte conteúdo apelativo e político, que mais das vezes redunda em arbítrio. No Brasil observamos o Legislativo assumindo as funções do Judiciário e do Ministério Público, com as já famosas Comissões Parlamentares de Inquérito - CPI. Como se dirá mais adiante, descentralizar o controle jurisdicional pode auxiliar na eficácia e prejudicar na isenção, devendo esta descentralização ser vista com muito cuidado.

A importância da garantia judicial foi ressaltada por Montesquieu, que elaborou a teoria da separação de poderes, erigindo justamente o Poder Judiciário como um dos três poderes. A idéia-força de Montesquieu sobre o Poder Judiciário foi levada a cabo nas diversas democracias do mundo, onde se estabeleceram prerrogativas das mais amplas a esse poder, de modo a alçá-lo ao ponto de chegar a ter um caráter de poder constituinte ${ }^{39}$

O excesso de Montesquieu não foi, todavia, sequer cumprido na própria França, como bem observa Ferreira Filho. Da época de Montesquieu viria,

39. Nos EUA, por cxemplo, o sistema de controlc judicial deu às decisões da Suprema Cortc um caráter de poder constituinte efetivo, diante da força de suas interpretações da Constituição, fazendo valer a célebre frase "Wc are under a constitution, but the constitution is what the judges say it is" (Chicf. Justice Charles Evans Hughes - United Statcs Supreme Court - Adress S. 139), traduzindo: "Nós cstamos sob uma constituição, mas a constituição ć o que os juízes dizcm que ć". 
provavelmente, a recusa em atribuir ao Judiciário o poder de invalidar leis. Em seu lugar, a Constituição francesa admite, há pouco mais de trinta anos, o Conselho Constitucional, colegiado de controle preventivo, cujas decisões são irrecorríveis e tem validade erga omnes ${ }^{40}$

Por outro lado, foi o Sistema Judiciário inglês que firmou os princípios e os remédios de direito fundamental que culminaram com a efetivação do controle judicial. Não elevado ao plano de Poder, porque não se considera a separação institucional de poderes na Inglaterra. Com razão estava e está a Inglaterra que, de certa forma, sempre desprezou a teoria da separação total de poderes, caminhando do absolutismo monárquico para uma separação relativa, mais notada nas relações entre o Legislativo e o Executivo. ${ }^{41}$

Relata Ferreira Filho o papel desempenhado pelos juízes itinerantes ingleses, revisores das decisões costumeiras locais (law of the land), desde 1175. Desenvolveu-se o papel de revisão judicial, acrescendo-se o poder de emitir ordens escritas para a garantia de direitos individuais, como os writs, o habeas corpus, o certiorari, a injunction, entre outros (p. 131).

As contribuições do Direito inglês não se limitaram aos remédios de direito fundamental. Os princípios fundamentais que hoje integram as constituições escritas modernas, como a legalidade, o devido processo legal, o controle de atos da administração e, por último, o controle de constitucionalidade, provêm todos do due process of law e do rule of law.

$\mathrm{O}$ due process of law, princípio bastante conhecido por nós, está dentre os direitos fundamentais do cidadão brasileiro, mais precisamente no art. 5, LIV e LV, da Constituição Federal. O devido processo legal, como bem assevera Ferreira Filho, na prática, significa dar ao litigante a mais ampla possibilidade de defesa de seus direitos perante o juiz, que vai, então, compor os interesses ou sancionar as condutas das partes envolvidas na lide, em face da lei. A garantia judicial prestada aqui é do Estado para o cidadão na defesa de seus direitos fundamentais.

Por outro lado, no rule of law, a garantia judicial é do Estado para o próprio Estado. O controle da administração pelo Judiciário pode se dar por meio de

40. Favorcu, Louis, Los tribunales constitucionales, Barcclona, 1994, p. 106.

41. Hegel, G. W. F., Sämtliche Werke-Grundlinien der Philosophie des Rechts, 368 . Para Hegcl, a scparação gera uma relação de desconfiança hostil, um crro que pode culminar com a desintegração do Estado. 
repressão a atos abusivos ou lesivos. Vinculado ao princípio da legalidade, o Poder Público tem aqui um julgamento que, atualmente, admite a apreciação judicial do mérito das decisões administrativas, o que representa uma ampliação da função jurisdicional. ${ }^{42}$

No Brasil, o constituinte brasileiro determinou ao funcionário público que pautasse seus atos seguindo não-só a lei, mas também outros elementos, como a moralidade. ${ }^{43}$ Por outro lado, permitiu o desfazimento de ato administrativo "lesivo ao patrimônio público e social", por meio de um remédio de direito como a ação popular. ${ }^{44}$ Como Ferreira Filho diz neste livro e no seu Curso de Direito Constitucional, o controle de atos administrativos permite ao juiz que aprecie a legalidade e outros princípios, segundo sua própria escala de valores (p. 135).

O princípio inglês do rule of law deu, portanto, ao controle judicial o direito de verificar a adequação geral de toda a vida do Estado, segundo o princípio da legalidade. Esta verificação, que Carl Schmitt definiu como "vollendete Ideal (pleno ideal)" do Estado de Direito, deu ao juiz uma prerrogativa perigosa da decisão política, ${ }^{45}$ posição sobre a qual concorda Ferreira Filho.

$\mathrm{Na}$ esteira do princípio do rule of law, veio o controle judicial da constitucionalidade das normas, tratado pelo autor como uma afirmação do governo de juizes, causa de um forte desequilíbrio na teoria da separação de Poderes, independentes e autônomos. Há quem diga, como o mesmo Kelsen, que o poder Judiciário, com a revisão judicial, propicia uma transgressão ao princípio da separação de poderes. ${ }^{46}$

Não-obstante, como Ferreira Filho relata (p. 136), a necessidade de garantir a supremacia da Constituição, por meio de um controle por meio de júri constitucional, fez dos EUA os pioneiros a impor esta regra no famoso caso Marbury versus Madison. Para fugir do debate que impedira a instauração da Corte constitucional na França, por infração ao princípio da separação dos poderes, o juiz Marshal teceu uma argumentação sólida, segundo a qual não haveria ingerência no Poder Legislativo na declaração de inconstitucionalidade da norma, pois esta já seria nula de pleno direito $a b$ initio, não merecendo sequer ser considerada como lei por afrontar a Lei Maior.

42. Ferrcira Filho, Manocl Gonçalves, Curso de Direito Constitucional, São Paulo, 27a. Edição, 200 J, p. 244.

43. Constituiç̧ão Federal, artigo 37.

44. Constituição Federal, artigo 129, III.

45. Schmitt Carl, Verfassungslehre, op. cit., p. 133/134.

46. Kclsen, Hans, General ..., op. cit., p. 269. 
Devemos analisar a interpretação das normas pelo Poder Judiciário, que foi inicialmente entendida pelos franceses do século XVIII como a análise de adequação das normas aos litígios concretos. Mais tarde, porém, a função do Judiciário foi ampliada, cabendo-lhe interpretar a adequação das normas à Constituição, criando-se, então, o controle de constitucionalidade. Por este controle avalia-se a adequação da norma inferior à norma superior que, utilizada como paradigma, na hipótese de inadequação, nega-lhe validade. Diante deste fato, a norma inconstitucional é vazia (do inglês "void"), legalmente inexistente, o que representa uma contradição em termos. ${ }^{47}$

O controle concreto de constitucionalidade desenvolvido nos EUA não retira a lei do ordenamento jurídico, declarando-a inconstitucional, tem validade entre as partes e efeitos ex tunc, podendo o cidadão acioná-lo incidentalmente, perante qualquer juiz. Este sistema do controle difuso de constitucionalidade foi trazido ao Brasil, expressamente previsto na nossa Constituição, já no início do século passado. ${ }^{48}$

Nosso sistema de controle de constitucionalidade difuso, no entanto, não tem o "stare decisis, " outro princípio trazido do Direito inglês, segundo o qual as decisões da Corte máxima firmam uma regra que deve ser seguida pelos tribunais ${ }^{40}$ Este princípio, utilizado de forma peculiar no Sistema americano, condena a lei ao "status" de letra morta, pois força os tribunais inferiores a entenderem da mesma forma que a Corte Suprema, impedindo que a norma inconstitucional opere (p. 136). Para suprir essa deficiência, o Sistema brasileiro de controle de constitucionalidade difuso prevê que o Senado Federal, após decisão definitiva do Supremo Tribunal Federal, suspenda a execução da norma tida como inconstitucional,,$^{50}$ o que acaba tendo um resultado semelhante ao do stare decisis americano.

47. Kelsen, Hans, General ..., op. cit., p. 155.

48. A Emcnda Constitucional de 5 de sctembro de 1926, alterou o art. $59 \mathrm{c}$ a Emenda Constitucional de 3 de setembro, de 1926, altcrou o art. 60 da Constituição de 1891, trazcndo a compctência do STF para apreciar recursos que dispusessem sobre a inconstitucionalidade de leis perante a Constituiçào - cf. Constituições do Brasil, organizado por Hilton Lobo Campanhole c Adriano Campanhole, São Paulo, 2000 , p.742.

49. Barros, Sćrgio Resende de, O Nó Górdio do Sistema Misto, artigo publicado no livro Argüição de Descumprimento de Preccito Fundamental: Análises à Luz da Lci n." 9.882/99, p. 181 - o autor interpreta o instituto, informando a sua locução complcta: "stare decisis et non quieta movere, ou, $\mathrm{cm}$ português, cstar com as coisas decididas c não mover as coisas quictas".

50. Não obstantc a Constituiçào Federal coloque a suspensão como uma competência (poder) privativa do Senado Federal (art. 52, X), Ferrcira Filho acertadamente entende como obrigatória a suspensão. Cf. Curso de Direito Constitucional, op. cit., p. 42. 
A função única do instituto do controle de constitucionalidade é a defesa da ordem jurídica, um meio de controle político, de modo que não infringe o princípio da separação de poderes. ${ }^{51}$ A justificativa desta afirmação está, também, no fato de a norma inconstitucional não ser aceita como tal, por lhe faltar um pressuposto essencial de validade, que é justamente a adequação à Lei Maior. ${ }^{52}$

O Judiciário não-revoga lei inconstitucional do Legislativo, uma vez que esta, reconhecida pela Corte Constitucional como incompativel com a Constituição, perde seu caráter de norma, " $a b$ initio", não conferindo poderes ao Executivo. ${ }^{53}$ Assim, portanto, não há como admitir que o controle de constitucionalidade levado a cabo pelo Judiciário interfira no princípio da independência e da separação total dos poderes.

Ferreira Filho conclui o capítulo do controle judicial, analisando o controle concentrado de constitucionalidade (p. 138). O controle inspirado no modelo austríaco, de 1920, foi adotado após a guerra na Itália, seguida da Alemanha, que lhe valeu o título de modelo europeu de controle de constitucionalidade.

Esse sistema europeu de constitucionalidade tem como principais características, não ser exercido pelo Poder Judiciário, não ser integrado por juízes de carreira e analisar a lei em abstrato, com decisão de efeito erga omnes. Esta característica do controle de constitucionalidade, critica Ferreira Filho, acentua o risco do governo dos juízes (p.139).

O Brasil adotou, além do sistema difuso de constitucionalidade, também o Sistema europeu de controle de constitucionalidade, diferenciado apenas por seu caráter não-político. O Supremo Tribunal Federal é a nossa corte constitucional que, provocada por determinadas autoridades, analise em tese a constitucionalidade de um ato normativo.

O controle de constitucionalidade brasileiro, como se vê, é bastante variado. Além do controle difuso, já descrito acima, o controle concentrado tem diversas

51. Mendes, Gilmar Ferreira, Moreira Alves e o Controle de Constitucionalidade no Brasil, São Paulo, 2000, p. 25 .

52. Accrtadamente, a Constituição imperial de 25 de março de 1824, trazia cm scu artigo 178: "É só constitucional o que diz respeito aos limites $\mathrm{c}$ atribuiçôes respectivas dos poderes políticos, c aos dircitos políticos c individuais dos cidadãos; tudo o que não ć constitucional pode ser alterado, sem as formalidades referidas pelas lcgislaturas ordinárias." - Constituições do Brasil, compilaçào de Hilton LOBO Campanhole c Adriano Campanholc, São Paulo, 2000.

53. Barbosa, Rui, A Constituição e os Atos Inconstitucionais do Congresso e do Executivo, Rio de Janciro, p. 42, apud Marques, Josć Fredcrico, O Dircito Processual cm São Paulo, São Paulo, 1977, p. 164. 
ações: a chamada ADIN, a Ação Direta de Inconstitucionalidade, prevista no art. 102, alínea 'a'. da Constituição Federal; a ADC, Ação Declaratória de Constitucionalidade, prevista no art. 103, parágrafo quarto da Constituição Federal:;4 a Ação de Argüição de Descumprimento de Preceito Fundamental, prevista no art. 102, I, da Constituição Federal ${ }^{55}$

Adiante, Ferreira Filho ressalta o importante papel desenvolvido pela Justiça Eleitoral para a democracia, regulamentando todo o processo eleitoral, que o autor entende ser inspirado na idéia de Kelsen, concretizado pela primeira vez na Tchecoslováquia, em 1920 (p. 140).

Novamente, ao finalizar seu capítulo do controle judicial, o professor da Faculdade de Direito da Universidade de São Paulo lança a dúvida sobre a politização do Judiciário ao assumir diversas funções, como o controle administrativo, controle de constitucionalidade normativa por via direta e controle eleitoral. O problema da politização da Justiça, analisado da mesma forma e com detalhe por Schmitt em seu Verfassungslehre, preocupa quando trata a Justiça, principalmente, de assuntos de Direito Público ${ }^{56}$

Para encerrar set: mais novo ensaio sobre a democracia, Ferreira Filho trata das condições instrumentais para a democracia, que o autor julga serem imprescindiveis para o seu funcionamento pleno.

Dentre as condições instrumentais que o autor descreve em seu trabalho está a opinião pública esclarecida e racional. Outra condição instrumental essencial é o sistema eleitoral eficaz, sem o que a democracia fica fragilizada, nas mãos de uma oligarquia que perpetua sua vontade e a defesa de seus interesses pessoais. Por último, o doutor honoris causa da Faculdade de Direito de Lisboa conclui ser imprescindível o sistema de governo.

54. Ambas açõcs foram recentemente regulamentadas pela Lei n. 9.868 , de 10 de novembro de 1999.

55. Faltou ao autor comentar cste tipo de controle de constitucionalidade, a que cle dedica um tópico $\mathrm{cm}$ seu Curso de Direito Consfitucional, op. cit., p. 40 - Esta importante ação $\mathrm{cm}$ defesa de preccito fundamental tem como objeto a decisão sobrc a inconstitucionalidadc ou-não de atos impugnados perantc juizes c tribunais que pode ser avocada pelo STF. O cidadão foi o grande bencficiado pela recentc regulamentação deste tipo de controle de constitucionalidade, com a Lci n. 9.882, de 3 de dezcmbro de 1999, que lhe deu um instrumento de defesa de scus dircitos fundamentais, travados por questõcs processuais ou regimentais, nas instâncias inferiorcs do pais.

56. Schmitt, Karl, op. cit. , p. 134. - O autor cita alguns cxemplos: a) tratamento cspccial dos delitos políticos; b)acusaçõcs contra ministros c presidentc; c) litigios constitucionais; d) análisc de dúvidas ou divergências de opinião sobre a constitucionalidade de Jcis ou regulamentos de um tribunal cspccial; c) tratamento especial dos atos de governo c atos políticos específicos no campo da administração; $t$ ) cxame de questõcs clcitorais. 
No que diz respeito à opinião pública esclarecida, analisa Ferreira Filho o processo de formação decorrente da alimentação por informações recebidas e processadas pelos indivíduos. As informações recebidas pelo cidadão devem ser analisadas de forma crítica, o que exige cultura e vivência social, voltando um pouco ao início do livro.

Também devem ser levados em conta os aspectos psicossociais, como o caráter do cidadão, sendo o "inner directed" o melhor tipo para desenvolver a opinião pública em prol da democracia.

Outro aspecto importante da opinião publica, abordado por Ferreira Filho (p. 152), é o instrumento de formação da opinião pública. Aqui podemos citar alguns, desde os mais tradicionais, como o jornal, a rádio e a televisão, até os mais modernos, como a Internet e os aparelhos celulares conectados à Internet em tempo real. Não podemos deixar de tratar, também, da propaganda e do poder econômico, instrumentos que têm sido decisivos no processo eleitoral.

O autor dá um destaque especial à televisão como instrumento de formação e, também, de deformação da opinião pública. Seu poder chegou a ser ameaçado no final do século passado, quando foi anunciada a Internet como sua substituta.

Essa ameaça, contudo, não passou de uma tentativa desesperada da economia americana em retardar os efeitos da crise sentida nos dias de hoje. Quanto à Internet como meio de comunicação de massas e de instrumento de formação de opinião pública, como o autor e outros cientistas políticos dizem, não se tem conhecimento de seu poder efetivo. É mais provável, entendemos, que ele se integre à televisão, como uma ferramenta capaz de ampliar o poder de interação do espectador com o comunicador. Exemplos como estes podem ser observados nos programas de televisão brasileiros, em que o telespectador é chamado a participar com seu "voto" de opiniões sobre a escolha do técnico da seleção brasileira de futebol, sobre o final de uma novela, etc..

Como bem destaca Ferreira Filho (p. 154), o poder da televisão não está somente ligado à informação que ela dá ao cidadão, mas também ao conteúdo personalizado e afetivo de suas imagens e sons, que turva a mente do espectador, impedindo que ele exerça sua crítica após alguma abstração. Nisso concorda Sartori, cientista social italiano que esteve em São Paulo, a convite do Instituto Pimenta Bueno, para falar de seu livro Homo videns - televisione e post pensiero, ${ }^{57}$ uma crítica mordaz ao poder da televisão.

57. Sartori, Giovanni, Homo videns - televisione e post pensiero, Milão, 1998. 
Em épocas eleitorais ou pré-eleitorais, como a que vivemos ao redigir este artigo, vemos com muita frequiência o que Sartori chama de desinformação ou subinformação, bem como a criação de acontecimentos. A distorção provocada pelo caráter afetivo das informações da televisão possibilita, por exemplo, que candidatos surjam com faces dóceis, prometendo estar mais maduros, lutar contra a corrupção e pelos pobres, encantando a "massa volla" com discursos demagógicos de fazer corar estátua.

Ainda sobre a questão da formação da opinião pública, Ferreira Filho aborda o problema dos perigos da manipulação das massas por parte dos comunicadores (p. 156). Como o indivíduo recebe as informações dos meios de comunicação, passivamente e com o espírito desarmado, toma essas informações com forte dose de presunção de veracidade.

Os comunicadores e os meios de comunicação assumem, então, um poder muito grande na formação da opinião pública, sendo capazes de construir e destruir mitos com uma facilidade impressionante. Ferreira Filho traz à colação de seu livro o caso do Washington Post, que fez uma campanha difamatória contra o presidente americano Richard Nixon, culminando com sua renúncia. Na esteira desse caso e mesmo antes ${ }^{58}$ os meios de comunicação e os comunicadores ${ }^{59}$ brasileiros disputam os escândalos políticos com grande voracidade. Atualmente, tem sido constantes as matérias publicadas nas maiores revistas semanais de atualidades do País, "Veja" e "Isto $\dot{e}$ " trazendo denúncias políticas que, dependendo da força com que são introduzidas, têm resultado na renúncia ou cassação de políticos, além da abertura de investigações e processos contra as mais variadas pessoas. ${ }^{60}$

Nem se diga dos programas televisivos e seus "âncoras" que são determinantes na formação da opinião pública. Dependendo da linha política desenvolvida por esses comunicadores e da maior oụ menor projeção que dão aos

58. Cf. Morais, Fcruando, Chatô O Rei do Brasil, Companhia das Letras, São Paulo, 1994, p. 449 c ss.

59. Lcmbramos a campanha do jornalista Carlos Laccrda contra Gctúlio Vargas, que resultou não apcnas com a renúncia, scnão no suicídio do presidente da República, $\mathrm{cm}$ facc da amcaça de cscárnio popular pela exploração de um fato cscandaloso cnvolvendo scu nome. Sobre Laccrda, vide Carlos Lacerda a Vida de Um Lutador, de Johın W.F. Dulles, Sào Paulo, 2000; sobre o poder da Imprensa brasilcira aconsclhamos, também, a Icitura de Minha Razão de Viver, de Samucl Waincr, São Paulo, 1987.

60. Há casos atuais, como o do ex-deputado Sérgio Naya, cassado de scu mandato de deputado fedcral, no calor de uma tragédia decorrente do desabamento do Edifício Palace II c recentemente absolvido, $\mathrm{cm}$ primcira instância, $\mathrm{cm}$ proccsso judicial que apura sua responsabilidade subjetiva no cvento. 
eventos políticos e aos políticos em si, podem desempenhar um papel determinante no jogo político das democracias modernas. ${ }^{61}$

Criticando o que ele denominou acidamente como "intelectuais," Ferreira Filho levanta o problema de um tipo social que transmite idéias e emite opiniões sobre fatos dos quais não-entende. Este tipo social exerce um papel determinante na midia em geral, correndo atrás dos fatos para emitir seu "parecer" sobre o caso. Entendemos que, num País como o Brasil, de recente valorização de suas instituições e afirmação de sua constituição, não faltam os "intelectuais" juristas, sempre prontos para falar sobre a constitucionalidade ou inconstitucionalidade de normas. Como bem ressalta o autor, esses "intelectuais" dependendo do grau de penetração que têm na mídia, fixam padrões de "verdade" a que os other directed aderem com grande facilidade.

Quanto à propaganda como meio de comunicação de massa na formação da opinião pública, Ferreira Filho faz uma breve análise, deixando claro que este meio é velho conhecido da ciência política e, hoje, vende desde um sabonete até uma candidatura (p. 159).

Este tema, dada a importância que assumiu nas democracias modernas, mereceria maior dedicação da doutrina. O profissional de propaganda assumiu, na última década, um papel determinante na formação de candidatos e na venda do "pacote político" do candidato para o público consumidor, o eleitorado. ${ }^{62}$

É interessante o registro das regras elaboradas por Domenach, ${ }^{6.3}$ trazidas pelo autor ao conhecimento do leitor, que valem a pena serem transcritas novamente: 1) de simplificação; 2) de exageração e desfiguramento; 3) de orquestração; 4) de transfusão; 5) de unanimidade. Essas regras demonstram uma técnica que, se bem utilizada pelo profissional de marketing e publicidade, podem mudar completamente as qualidades pessoais de um candidato, transformando a relação político-eleitor, de mandato representativo, numa relação de consumo, um "produto" que o cidadão "other

61. Citcmos o recentc caso da clcição americana, $\mathrm{cm}$ que os dois candidatos estiveram tecnicamentc cmpatados nas pesquisas de opinião atć o último debatc, transmitido com recordes de audiĉncia, cm quc o atual presidenté Bush saiu vitorioso do debate c da cleição.

62. Podemos citar o trabalho de grandes publicitários brasilciros para a cleição de presidente, governadores c prefcitos, como Nizan Guanacs c Duda Mendonça, cstc último responsávcl pcla campanha malsuccdida para mudar a fama polĉmica do ex-prcfcito Paulo Maluf, adotando o slogan "rouba mas faz", hoje cnvolvido cm novo desafio, de mudar a fama maoísta de Luis Inácio Lula da Silva, para vender mclhor sua candidatura à presidĉncia, com novo slogan "mais maduro"

63. Domench, V. J. M., La propagande politique, Paris, 1959, p. 15 c ss. 
directed" somente se dará conta de suas virtudes reais após a eleição, quando não terá senão a próxima eleição para se arrepender da má escolha.

Outro tema de grande importância para a ciência política hodierna, trazida ao leitor com a síntese precisa de Ferreira Filho, é a manifestação da opinião pública. A "boca pequena" do povo, hoje traduzida em sondagens de opinião, um instrumento valioso nas mãos dos comunicadores, da mídia e dos profissionais de marketing político.

A este respeito deveriam, também, os estudiosos de ciência política dedicarem mais a sua atenção, pois as sondagens de opinião públicas têm crescente utilização em todo o cenário democrático, seja no sufrágio, seja na formação da opinião pública, com relação aos fatos de seu interesse direto, como diante das medidas adotadas pelo governo democraticamente eleito.

A técnica das sondagens de opinião é de certa forma ignorada por boa parte dos sujeitos às mesmas sondagens, ou seja, os cidadãos. A metodologia científica na elaboração das questões, a qualidade do público alvo, o número de entrevistados e o tempo e época dedicados à sondagem podem modificar completamente os resultados obtidos. A falta de técnica e o modo tendencioso com que se utilizam as sondagens de opinião revelam que esses instrumentos, que deveriam servir para a expressão da "vox populi", em verdade servem aos comunicadores, à mídia e aos profissionais de marketing para conduzir os "other directed" a pensarem e agirem de determinada forma ${ }^{64}$

Há de se ter cuidado, portanto, com as sondagens de opinião pública nas democracias, pois elas deveriam aumentar a racionalidade das opções ou decisões populares, o que não-ocorre, como constata Ferreira Filho, respaldado por estudiosos no assunto. ${ }^{65}$ Sugerimos, então, que se estabeleçam institutos isentos ou agências privadas, sob os auspícios do Ministério da Justiça ou da Justiça Eleitoral, para regulamentar e policiar os institutos de pesquisa, evitando que eles sejam utilizados para a manipulação das massas.

64. Um cxemplo atual c doméstico da má utilização das sondagens se viu na recente pesquisa divulgada, cm 18 de junho de 2001, pclo sitc Veja On-linc, scgundo a qual 42,2\% dos cntrcvistados acreditavam que a incompctência do Governo federal causou a crisc no sistema encrgético; $27,4 \%$ acreditavam que cla se deve à falta de chuvas; $14,4 \%$ atribui a crisc à falta de investimentos c 10,2\% viam as privatizaçõos como responsávcis pcla crisc. Vê-sc, primciramente, que a matćria submctida ao crivo público, ć muito técnica c, também, que as perguntas realizadas, à exccção de uma, visam rcsponsabilizar o Governo dircta ou indirctamente pela crise encrgética, o que vicia a sondagem, por falta de qualidade cientifica para provar o que quer que seja.

65. Sartori, Homo videns..., op. cit., p. 75, c Lamounicr, Bolivar, A Democracia brasilcira no limiar do sćculo XXI, in Pesquisas, São Paulo, Fundação Konrad Adenaucr, 1996, p. 35. 
Finalizando o capítulo, Ferreira Filho ressalta o papel do Estado no controle dos meios de comunicação de massa, que no Brasil estabeleceu o chamado "horário gratuito" criou o direito de resposta aos candidatos ofendidos por seus opositores, dando ao Judiciário o papel de controle democrático do Estado. A idéia, como o autor já dissera anteriormente, citando Carl Schmitt, por um lado positivo, coroa o Estado de Direito, mas por outro negativo, propõe um perigoso desvio de funções ${ }^{66}$

Tratando de um tema de crucial importância instrumental para a Democracia, Ferreira Filho aborda o Sistema de Governo, no capítulo 13 de seu livro. O foco principal desta discussão sobre Sistema de Governo está na garantia de governabilidade com a participação ideal do povo na formação da vontade geral.

A teoria da separação de poderes, diante da importância que Montesquieu lhe deu em seu De l'Esprit des lois, passou a ser considerada não-só como um elemento de limitação do poder absoluto, mas também a base para um Sistema de Governo que premiasse a legalidade. Por diversas passagens de seu livro, em especial ao tratar da "constituição da Inglaterra," Montesquieu pretendeu forçar essa idéia, dizendo não haver liberdade sem separação de poderes, estando tudo perdido se o mesmo homem, o mesmo corpo, ou os nobres ou o povo exercesse os três poderes. ${ }^{67} \mathrm{O}$ exagero proposital de Montesquieu partiu de uma interpretação deliberadamente distorcida do Sistema inglês, que mantinha e, de certa forma, mantém até hoje, o Executivo, Legislativo e Judiciário, separados apenas como funções de um único Estado, ao nosso ver o modelo mais racional.

O problema de relacionamento das funções legislativa e executiva do Estado, para o qual Ferreira Filho chama a atenção do leitor (p. 191), está na eficácia da separação independente deles como poderes levar a certa ingovernabilidade, caso fracasse um Sistema de Governo que modere os ímpetos de independência e de autoritarismo.

Os sistemas de Governo que mais se destacaram ao longo da história foram o presidencialismo, o parlamentarismo, o diretorial e o misto. O primeiro deles tem como característica principal a separação dos poderes e a figura forte do chefe do Executivo. O parlamentarismo, o mais antigo dos sistemas, não considera a separação de poderes, adotando um sistema de interdependência total das funções executiva,

66. Verfassungslehre, op. cit., p. 134.

67. Op. cit., p. 328. 
legislativa e certa independência judiciária, com a característica de um chefe de Governo vindo do próprio parlamento. O sistema diretorial, existente hoje apenas na Suíça, tem sua característica marcante na idéia de um governo não de um, mas de um diretório, que cumpre as diretrizes do parlamento de que também faz parte. O sistema misto de parlamentarismo e presidencialismo é basicamente um sistema parlamentar com alguns traços de presidencialismo, que dá ao chefe de Estado alguns atributos capazes de manter o equilíbrio de forças entre os poderes Executivo e Legislativo, trabalhando como um poder moderador que pode dissolver o parlamento e consultar o povo, em questões de relevante importância, por meio de referendo.

No Brasil vivemos recentemente o dilema dos sistemas de governo, quando a Constituição Federal, de 1988, estabeleceu que o povo decidiria, por meio de plebiscito, a forma (república ou monarquia constitucional) e o sistema de governo (parlamentarismo ou presidenciališmo). ${ }^{68}$ A dúvida dos constituintes da época era definir o melhor sistema de Governo, que impedisse o excesso de poderes do Executivo ${ }^{(1)}$

A bem da verdade, a discussão em torno dos sistemas de Governo está longe de ter uma definição, pois as tarefas do Estado Social de Direito não param de crescer, competindo à administração cuidar da garantia dos direitos sociais sem descuidar da economia e, mais recentemente, fazer-se respeitar internacionalmente, por meio de uma participação efetiva nos organismos supranacionais.

Observamos com preocupação os ataques ferozes ao deslocamento do Poder Legislativo para o chefe do Poder Executivo, por meio das polêmicas medidas provisórias, que deveriam ser utilizadas como instrumento emergencial e, de fato, constituem um verdadeiro meio legislativo do presidente da República. Isto acaba por configurar o que Resende de Barros chama de presidentismo ${ }^{70}$ Muito embora concordemos com a crítica aos excessos do Poder Executivo no meio normativo, devemos analisar o problema diante da incapacidade do Legislativo de atender à

68. Constituição da República Federativa do Brasil, de 5 de outubro de 1988, artigo segundo do Ato das Disposiçõcs Constitucionais Transitórias.

69. Para quem acompanhou os Anais da Assemblćia Nacional Constituinte ć forçoso lembrar que os defensorcs do parlamentarismo são os mesmos quc hojc abusam da posição confortável do presidencialismo, com o uso das combatidas medidas provisórias, dando razão aos que denominaram o presidentc como "His Majesty, the President of Brasil" (livro citado pelo autor, de autoria de Ermest Hambloch, Nova York, Dutton, 1936).

70. Resende de Barros, Sćrgio, Medidas, Provisórias?, in Revista da Procuradoria Geral do Estado de São Paulo, n. 53, junho/2000, pp. 67/82. O autor criou o termo presidentismo para designar a deturpação do presidencialismo no Brasil. 
demanda normativa do Estado." A discussão estéril da independência dos poderes e da reserva legal culmina, como ocorre na Itália, com a hipócrita delegação disfarçada de poderes do Legislativo ao Executivo, cunhada como "delegificazione" por Giuseppe de Vergottini. ${ }^{72}$ A simples limitação do poder executivo no exercício da atividade normativa gera a paralisação das ações do governo que, num sistema parlamentar, gera a constante alteração de governos, como ocorre na Itália e, no sistema presidencial, deixa o governo refém do parlamento, que no Brasil tem dado margem a toda a sorte de corrupção.

Na comparação entre os sistemas de Governo, deixa o autor transparecer sua preferência pelo sistema misto, embora reconheça a dependência cultural política para que este sistema tenha êxito (p. 213). A proposta de Ferreira Filho parece fustigar o leitor a refletir de modo racional diante de um problema que preocupa cada vez mais os cientistas políticos devido a modernização das relações jurídicas.

Para o sucesso de qualquer sistema de Governo, além da cultura política é essencial adequação deste à representatividade e ao sufrágio, de modo que a democracia permita por um lado a maior participação popular possível, sem prejudicar a administração do Estado. ${ }^{73}$ Por sua vez, a representação não está diretamente ligada com a mera existência de procedimentos democráticos de legitimação, de formação da vontade geral e da decisão, mas sim na forma como se efetivam esses processos. ${ }^{74}$

Encerrando este que é, sem dúvida, um livro que não pode faltar nas bibliotecas dos estudiosos da Ciência Política brasileira, Ferreira Filho fala do futuro da democracia. Aqui a ciência aproxima o autor a Norberto Bobbio, ${ }^{75}$ pois ambos, ao contrário dos "other directed" que anunciam a mundialização da democracia, vêem com ressalvas a afirmação de que o mundo é ou deve ser democrático. Neste livro, como em palestra proferida no $8^{\circ}$ Encontro Nacional de Direito Constitucional,

71. Noticiamos a recentc aprovação da EC n. 32, de 11 de setembro de 2001 , que limita o uso das Medidas Provisórias, devendo ser sancionada pelo presidente da República, sobre a qual escreveremos futuramente.

72. A "Delegificação" e a sua Incidência no Sistema de Fontes do Direito, traduzido por Fernando Aurclio Zilveti, in Direito Constitucional Estudos em Homenagem a Manoel Gonçalves Ferreira Filho, coordenado por Sérgio Rescnde de Barros c Fcrnando Aurclio Zilveti, São Paulo, pp. 163/178.

73. Böckenfördc, Enst Wolfgang, Estudios sobre el Estado de Derecho y la democracia, Madrid, 2000 , p. 154.

74. Böckenföfdc, Ernst Wolfgang, idcm.

75. II Futuro..., op. cit., p. 199. 
organizado pelo Instituto Pimenta Bueno - Associação Brasileira dos Constitucionalistas, Ferreira Filho aponta que a democracia, assim como boa parte dos valores ocidentais, não encontra eco em diversas culturas, como a muçulmana, hindu, chinesa, nipônica e etc.

O capitalismo é a "bola da vez" na atenção das esquerdas radicais, que promovem ações totalitárias contra símbolos do capitalismo, empresas multinacionais, como o McDonald's, ou mesmo contra os EUA. Falta, porém, aos marxistas uma proposta alternativa ao liberalismo, tendo que se render a contragosto ao sistema existente e dominante na atualidade. O perigo destas posições estremadas é que elas promovam, como vem ocorrendo na Colômbia, com a FARC, e no interior do Brasil, com o MST, movimentos para a inviabilização da democracia, como bem atenta o autor (p. 218).

Em que pese um movimento mundial progressivo de certa democratização, com o respeito aos direitos fundamentais, à legalidade, à separação de poderes e ao sufrágio universal, se a democracia é uma utopia perseguida há muito tempo em boa parte dos países ocidentais, a extensão dela para todo o mundo, é uma "idea della ragion pura, che può valere in pratica soltanto come un'idea relativa"

Considerando a dependência crescente dos países em relação aos organismos internacionais como, por exemplo, o Fundo Monetário Internacional-FMI, a Organização Mundial do Comércio-OMC, a Organização do Tratado do Atlântico Norte-OTAN, sem contar a recente organização de estados supranacionais como o Mercado Comum Europeu, o Mercosul e a recente Área de Livre Comércio das Américas-ALCA, a democratização nacional depende da democratização internacional, sendo que o adimplemento de um obstáculo para o outro, como diz Bobbio, ${ }^{77}$ dificilmente se realizaria, como diz Ferreira Filho, pois estes estados supranacionais são pouco receptivos à idéia de democracia (p. 222).

A modernização veloz da tecnologia ${ }^{78}$ e da economia pela qual passa a Humanidade é, sem dúvida, o motor de popa da democratização mundial, pois ela

76. Idcm, p. 218.

77. Idcm ibidem, p.218.

78. A tecnologia da Internet $\dot{c}$ um excmplo de um canal de ingresso dos países para o libcralismo, prova disso ć o acesso à rede por parte de cidadãos do mundo islâmico, que proibc o accsso à comunicação, que participam das redes de "chats," pedindo ajuda internacional para acabar com a ditadura politica cm scus paises. 
força a estandardização das culturas e, conseqüientemente, pressiona todas as civilizações a modificarem seus sistemas ancestrais de cultura, de religião, de economia e, por último, de governo.

Se o McMonde em que vivemos hoje é de fato uma civilização calcada em direitos fundamentais e em um sistema econômico do capitalismo democrático, ${ }^{79}$ o desafio para o novo século é fortalecer a democracia onde ela exista para, daí, expandila para onde ela se faça necessária.

Grandes constitucionalistas da atualidade, como Böckenförde, parecem ter a mesma visão de Ferreira Filho sobre o futuro da democracia, propondo a ampliação da cultura política, aqui entendida da mesma forma ampla que ele prega desde seu livro $A$ Democracia Possivel, como condição de existência da democracia. ${ }^{80}$

Podemos, afinal, depreender do livro A Democracia no Limiar do Século $X X I$, São Paulo, 2001, R\$ 26,00, que a proposta de reflexão do autor para o novo século é de que o pensamento liberal vai nos livrar do dilema de como promover a ampliação segura da democracia, e permitir a busca incessante da liberdade individual por meio do exercício da liberdade coletiva.

79. Sorman, Guy, Le Monde est ma tribu, Paris, Fayard, 1997, p. 23. O autor cria o tcrmo Mc Monde numa menção ao McDonald's, cadcia de restaurantes que se cspalhou de forma notável por todo o mundo, inclusive cm paíscs não democráticos ou com grande fragilidade institucional.

80. Böckenfördc, Ernst Wolfgang, Estudios ..., op. cit., p. 158 


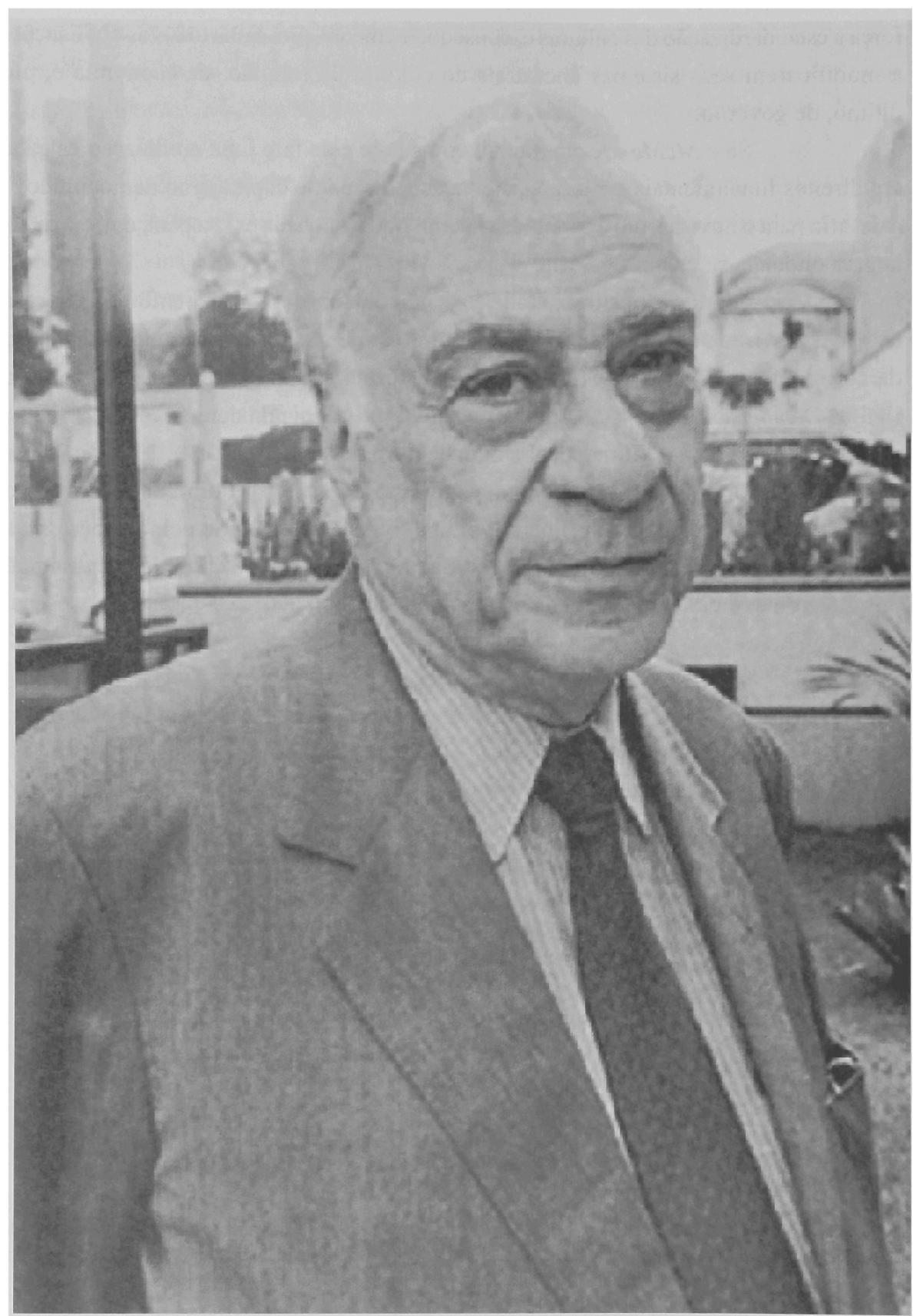

Professor Manoel Gonçalves Ferreira Filho 